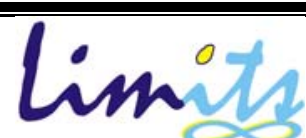

Limits: Journal of Mathematics and Its Applications

E-ISSN: 2579-8936

P-ISSN: $1829-605 \mathrm{X}$

Vol. 17, No. 1, Juli 2020, 67-81

DOI: http://dx.doi.org/10.12962/limits.v17i1.6694

\title{
Kontrol Optimal pada Model Penyebaran Virus Influenza Tipe A H1N1 dengan Menggunakan Prinsip Minumum Pontryagin
}

\author{
Indah Rahmadhania ${ }^{1}$, Didik Khusnul Arif ${ }^{2}$ \\ ${ }^{1,2}$ Institut Teknologi Sepuluh Nopember (ITS) \\ ${ }^{1,2}$ Departemen Matematika, Fakultas Sains dan Analika Data \\ e-mail: indahrahmadhania@gmail.com¹,didik@matematika.its.ac.id ${ }^{2}$
}

Diajukan:10 Maret 2020, Diperbaiki: 27 Juni 2020, Diterima:13 Juli 2020

\begin{abstract}
Abstrak
Penyakit menular pada suatu populasi dapat diprediksi dengan menggunakan model matematika epidemik. Salah satunya yaitu virus Influenza tipe A H1N1. Influenza H1N1 merupakan panyakit pernafasan akut pada manusia yang mempengaruhi hidung, tenggorokan dan paru-paru yang disebabkan oleh virus influenza H1N1. Penyakit ini mudah menular. Sehingga perlu diketahui mengenai penyebaran penyakit tersebut agar penyebarannya dapat dikendalikan. Pada paper ini, model matematika SEIR digunakan untuk membahas penyebaran virus influenza tipe A (H1N1), di mana populasi terbagi ke dalam empat kelas yaitu sub-populasi rentan, terpapar, terinfeksi, dan sembuh. Analisis yang telah diperoleh dari model tanpa dan dengan kontrol diilustrasikan dengan simulasi numerik menggunakan program Matlab berdasarkan metode Runge-Kutta Orde Empat dan Sweep Forward-Backward. Berdasarkan simulasi numerik menunjukkan bahwa pemberian kontrol untuk pengendalian lingkungan berupa penyuluhan, seminar dan kerja bakti dapat memaksimalkan jumlah individu yang sehat sedangkan kontrol dalam upaya pemberian obat terhadap individu terinfeksi influenza dapat meminimalkan jumlah indivisu yang terinfeksi.
\end{abstract}

Kata Kunci: virus influenza, kendali optimal, prinsip minimum pontryagin, Runge-Kutta.

\begin{abstract}
Infectious diseases in a population can be predicted using epidemic mathematical model.One of which is Influenza virus type A H1N1. H1N1 influenza is an acute respiratory disease in humans that affects the nose, throat and lungs caused by the H1N1 influenza virus. This disease is contagious. So,it is necessary to know the spread of the disease so that its spread is controlled. In this final project, the SEIR mathematical model is used to discuss the spread of influenza type A (H1N1) viruses, in which the population is divided into four classes namely susceptible, exposed, infected, and recovered sub-populations. The analysis that has been obtained from models without and with control is illustrated by numerical simulations using the Matlab program based on the Fourth Order Runge-Kutta and Sweep Forward-Backward Method. Based on numerical simulations, we show that the provision of controls for environmental control in the form of counseling, seminars and community service can maximize the number of healthy individuals while control in the effort to administer drugs to influenza-infected individuals can minimize the number of infected individuals. Keywords: Influenza Virus, Optimal Control, Pontryagin Minimum Principles, Runge-Kutta. Keywords: influenza virus, optimal control, Pontryagin Minimum Principle, Runge-Kutta method
\end{abstract}

\section{Pendahuluan}

Penyakit menular adalah penyakit yang disebabkan oleh sebuah agen biologi seperti virus, bakteri, atau parasit. Suatu individu dapat terjangkit penyakit menular melalui kontak langsung 
maupun tidak langsung dengan individu terinfeksi. Akibat kontak antar individu tersebut terjadilah suatu infeksi baru yang menjadi tanda adanya kasus penyebaran penyakit menular. Penyebaran penyakit menular yang terus terjadi akan mengakibatkan kondisi yang disebut epidemi. Perkembangan ilmu pengetahuan di dalam matematika juga turut memberikan peranan yang penting dalam mencegah meluasnya penyebaran penyakit. Peranan tersebut berupa model matematika yang dapat menggambarkan penyebaran suatu penyakit di masa yang akan datang dengan melihat kondisi masa sekarang atau masa lalu. Model matematika tersebut disebut model epidemi. Secara umum, model epidemi mempertimbangkan tingkat kejadian terinfeksi penyakit (incidence rate). Tingkat kejadian infeksi menyatakan banyaknya kasus infeksi baru akibat interaksi antara individu rentan dengan individu terinfeksi.

Dalam beberapa waktu terakhir, penyebaran penyakit menular terjadi dalam bentuk yang beragam, seperti pada penyakit Influenza H1N1. Keberagaman yang terjadi yaitu adanya perbedaan periode exposed dalam setiap individu yang terinfeksi virus H1N1. Terdapat individu yang melewati fase exposed, dan ada yang tidak. Hal tersebut terjadi karena variasi virus dan keadaan jasmani yang berbeda dari setiap individu.

Beberapa literatur telah membahas tentang penyabaran penyakit menular Influenza A H1N1. Pada tahun 2003, Neil dan rekannya [1] membangun model matematika simulasi penularan influenza efek terapi penghambat neuraminidase pada tingkat infeksi dan penularan virus yang resistan terhadap obat. Mereka berkonsentrasi pada penyelidikan numerik tanpa mempertimbangkan stabilitas model. Baru-baru ini, Zhou dan Guo [2] menganalisis model influenza dengan vaksinasi. Selanjutmya Nguyen Huu Khanh pada tahun 2015 dengan judul "Stability analysis of an influenza virus model with disease resistance"[3]. Pada penelitian ini mempelajari model baru yang menggambarkan penularan virus influenza tipe A dengan resistansi penyakit pada manusia.

Dalam paperini membahas model penyebaran virus influenza tipe A H1N1 dengan memasukkanparameter kontrol yaitu pemberian obat influenza pada individu terinfeksi dan pengendalian lingkungan berupa penyuluhan, seminar dan juga kerja bakti sebagai upaya dalam mengendalikan penyebaran penyakit. Setelah itu akan dilakukan simulasi dari penyelesaian numerik metode Runge-Kutta Orde Empat menggunakan software MATLAB.

\section{Metode Penelitian}

Pada penelitian ini, pertama kali dilakukan penentuan titik setimbang model, melakukan linearisasi dengan mengunakan matriks jacobian, menganalisa kestabilan dari titik setimbang 
untuk mengetahui sistem tersebut itu stabil atau tidak, dan menganalisis keterkontrolan sistem. Selanjutnya dilakukan perancangan masalah kontrol optimal dari model yang meliputi membentuk fungsi objektif serta kondisi syarat batas yang harus dipenuhi. Berikutnya penyelesaian kontrol optimal dapat dicari dengan menggunakan Prinsip Minimum Pontryagin yaitu membentuk fungsi Hamiltonian, menentukan persamaan state dan costate, menentukan kondisi batas yang harus dipenuhi, dan menentukan kontrol optimal. Sehingga dapat dicari solusi numerik menggunakan metode Runge-Kutta orde empat dari permasalahan kontrol optimal pada model. Kemudian disimulasikan untuk melihat pengaruh kontrol system pada grafik yang dihasilkan dengan menggunakan software Matlab versi R2013a.

\section{Model Sistem}

Model dinamik penyebaran virus influenza yang dibahas pada paper ini adalah model dinamik menurut Nguyen Huu Khanh [3] yang meninjau model SEIR terbaru yang menggambarkan penularan virus influenza dengan resistensi penyakit pada manusia.

Adapun asumsi-asumsi dalam model penyebaran penyakit influenza menurut Nguyen Huu Khanh [3] sebagai berikut:

1. Populasi bersifat tertutup yang berarti bahwa pertambahan atau pengurangan jumlah individu melalui emigrasi dan imigrasi tidak diperhatikan.

2. Populasi terbagi menjadi 4 bagian yaitu $S(t)$ subpopulasi individu rentan, $E(t)$ individu terpapar, $I(t)$ Individu yang terinfeksi dan $R(t)$ individu yang sembuh.

3. Terjadi pada lingkungan homogen dengan laju kelahiran dan laju kematian diasumsikan sama. Setiap individu yang lahir masuk kedalam kelas individu Susceptible dan setiap individu yang mati dari setiap kelas mempunyai laju proporsional dengan jumlah individu pada masing-masing kelas.

4. Dalam model ini, individu yang terpapar dan yang terinfeksi dapat kembali ke kelmpok rentan tanpa pengobatan.

Berdasarkan uraian penyebaran penyakit influenza tersebut, dapat disusun diagram kompartemen sebagai berikut : 


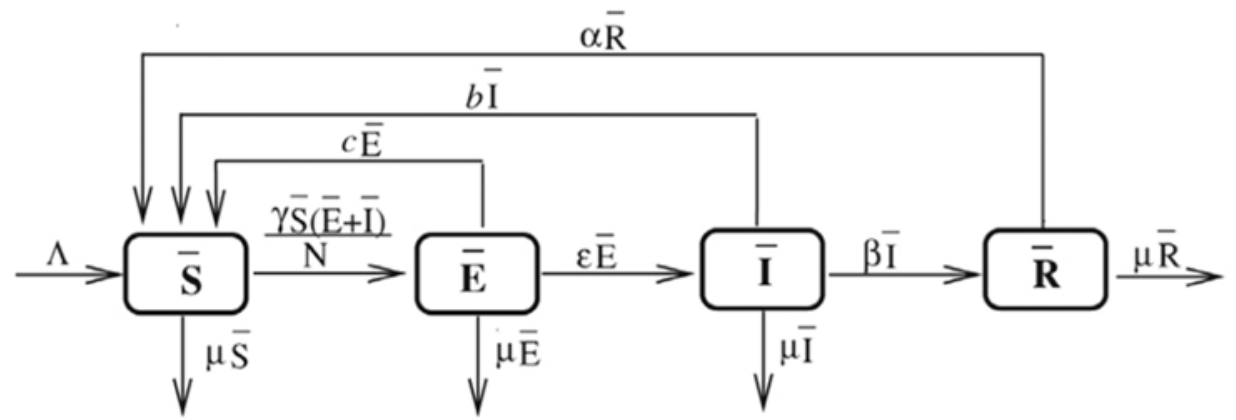

Gambar 1. Diagram Kompartemen Model Matematika Penyebaran Virus Influenza Tipe A

dengan,

$\bar{S}(t)$ : jumlah individu yang sehat dan rentan terhadap penyakit pada saat $\mathrm{t}$

$\bar{E}(t)$ : jumlah individu yang terpapar pada saat $\mathrm{t}$

$\bar{I}(t)$ : jumlah individu yang terinfeksi pada saat $\mathrm{t}$

$\bar{R}(t)$ : jumlah individu yang sehat setelah menjalani pengobatan pada saat $\mathrm{t}$

$\Lambda \quad$ : rekruitmen individu rentan.

$\mu \quad$ : rate kelahiran atau kematian alami

$b \quad$ : rate individu infected menjadi susceptible tanpa pengobatan.

$c \quad$ : rate individu exposed menjadi susceptible tanpa pengobatan.

$\varepsilon \quad:(\varepsilon=1 /$ IIP $)$, dimana IPP adalah periode inkubasi virus.

$\alpha \quad$ : rate individu recovered menjadi susceptible lagi

$\beta \quad$ : rate individu infected menjadi recovered.

$\gamma \quad$ : rate kontak penularan virus

Berdasarkan diagram kompartemen diatas, model matematika penyebaran virus influenza tipe A dapat disajikan dalam sistem persamaan diferensial sebagai berikut:

$\frac{d \bar{S}}{d t}=\Lambda-\gamma \bar{S}(t)\left(\frac{\bar{E}(t)+\bar{I}(t)}{N(t)}\right)+c \bar{E}(t)+b \bar{I}(t)+\alpha \bar{R}(t)-\mu \bar{S}(t)$

$\frac{d \bar{E}}{d t}=\gamma \bar{S}(t)\left(\frac{\bar{E}(t)+\bar{I}(t)}{N(t)}\right)-(c+\varepsilon+\mu) \bar{E}(t)$,

$\frac{d \bar{I}}{d t}=\varepsilon \bar{E}(t)-(\beta+b+\mu) \bar{I}(t)$,

$\frac{d \bar{R}}{d t}=\beta \bar{I}(t)-(\alpha+\mu) \bar{R}(t)$,

dengan kondisi awal $N(t)=\bar{S}(t)+\bar{E}(t)+\bar{I}(t)+\bar{R}(t)$.

Selanjutnya berdasarkan Persamaan (1), akan dicari laju pertumbuhan populasi manusia sebagai berikut:

$\frac{d}{d t} N(t)=\frac{d}{d t}[\bar{S}(t)+\bar{E}(t)+\bar{I}(t)+\bar{R}(t)]$ 
$\Leftrightarrow \frac{d}{d t} N(t)=\Lambda-\mu N$,

$\Leftrightarrow N(t)=-\frac{1}{\mu}\left(\frac{1}{c} e^{-\mu t}-\Lambda\right)$.

Dari persamaan pertumbuhan populasi manusia (2), terlihat bahwa semakin besar nilai t atau semakin lama waktu yang dibutuhkan, maka nilai $\frac{1}{c} e^{-\mu t}$ akan semakin besar. Hal ini bisa dinyatakan sebagai berikut: $\limsup _{t \rightarrow \infty} N(t)=\lim _{t \rightarrow \infty}-\frac{1}{\mu}\left(\frac{1}{c} e^{-\mu t}-\Lambda\right)=\frac{\Lambda}{\mu}$.

Berdasarkan Persamaan (3) terlihat bahwa jumlah populasi tak konstan. Jadi $N(t)$ memiliki batas atas yaitu $\frac{\Lambda}{\mu}, N(t) \in\left[0, \frac{\Lambda}{\mu}\right]$.

Untuk menyederhanakan sistem PD (1), dilakukan proses nondimensialiasi dengan menggunakan asumsi-asumsi sebagai berikut:

$S(t)=\frac{\bar{S}(t)}{N} ; E(t)=\frac{\bar{E}(t)}{N} ; I(t)=\frac{\bar{I}(t)}{N} ; R(t)=\frac{\bar{R}(t)}{N}$.

Sehingga sistem PD (1) dapat dituliskan sebagai berikut:

$\left.\frac{d S}{d t}=\mu-\gamma S(t)(E(t))+I(t)\right)+c E(t)+b I(t)+\alpha R(t)-\mu S(t)$,

$\frac{d E}{d t}=\gamma S(t)(E(t)+I(t))-(c+\varepsilon+\mu) E(t)$,

$\frac{d I}{d t}=\varepsilon E(t)-(\beta+b+\mu) I(t)$,

$\frac{d R}{d t}=\beta I(t)-(\alpha+\mu) R(t)$,

dengan kondisi,

$S(t)+E(t)+I(t)+R(t)=N ; S>0, E \geq 0, I \geq 0, R \geq 0$.

Selanjutnya Persamaan (4) disebut sebagai sistem awal tanpa kontrol.

\section{Analisis Sistem Awal Tanpa Kontrol}

1. Titik Setimbang

Keadaan setimbang merupakan kondisi dimana perubahan jumlah populasi sepanjang waktu adalah 0 . Model penyebaran virus Influenza dikatakan setimbang jika $\dot{S}=\dot{E}=\dot{I}=\dot{R}=0$ sehingga diperoleh:

a. Titik setimbang non endemik,

$$
E_{0}=\left(S^{0}, E^{0}, I^{0}, R^{0}\right)=(1,0,0,0)
$$

b. Titik setimbang endemik

Misalkan titik setimbang endemik dinyatakan dengan $E=\left(S^{*}, E^{*}, I^{*}, R^{*}\right)$, maka diperoleh titik setimbang endemik dari model penyebaran penyakit Influenza, dengan : 


$$
\begin{array}{cc} 
& \mathrm{S}^{*}=\frac{\gamma(\beta+b+\mu+\varepsilon)(\beta+b+\mu+\varepsilon)}{\left(\gamma(\beta+b+\mu+\varepsilon)+(c+\varepsilon+\mu) R_{0} \varepsilon\right)(\beta+b+\mu) R_{0}} \\
E^{*}=\frac{P}{Q} & I^{*}=\frac{(c+\varepsilon+\mu) R_{0} \varepsilon}{\gamma(\beta+b+\mu+\varepsilon)}\left(\frac{P}{Q}\right) \\
R^{*}=\frac{\beta \varepsilon}{(\beta+b+\mu)(\alpha+\mu)}\left(\frac{P}{Q}\right)
\end{array}
$$

dengan nilai:

$$
\begin{gathered}
\mathrm{R}_{0}=\frac{\gamma(\beta+\mathrm{b}+\mu+\varepsilon)}{(\mathrm{c}+\varepsilon+\mu)(\beta+\mathrm{b}+\mu)} \\
\mathrm{P}=\mu-\mu\left(\frac{\gamma(\beta+\mathrm{b}+\mu+\varepsilon)(\beta+\mathrm{b}+\mu+\varepsilon)}{\left(\gamma(\beta+\mathrm{b}+\mu+\varepsilon)+(\mathrm{c}+\varepsilon+\mu) \mathrm{R}_{0} \varepsilon\right)(\beta+\mathrm{b}+\mu) \mathrm{R}_{0}}\right) \\
Q=\left\{\gamma\left(\frac{\gamma(\beta+b+\mu+\varepsilon)(\beta+b+\mu+\varepsilon)}{\left(\gamma(\beta+b+\mu+\varepsilon)+(c+\varepsilon+\mu) R_{0} \varepsilon\right)(\beta+b+\mu) R_{0}}\right)-c\right. \\
+\gamma\left(\frac{\gamma(\beta+b+\mu+\varepsilon)(\beta+b+\mu+\varepsilon)}{\left(\gamma(\beta+b+\mu+\varepsilon)+(c+\varepsilon+\mu) R_{0} \varepsilon\right)(\beta+b+\mu) R_{0}}\right)\left(\frac{(c+\varepsilon+\mu) R_{0} \varepsilon}{\gamma(\beta+b+\mu+\varepsilon)}\right) \\
\left.-b\left(\frac{(c+\varepsilon+\mu) R_{0} \varepsilon}{\gamma(\beta+b+\mu+\varepsilon)}\right)-\alpha\left(\frac{\beta \varepsilon}{(\beta+b+\mu)(\alpha+\mu)}\right)\right\}
\end{gathered}
$$

\section{Bilangan Reproduksi Dasar}

Penentuan $R_{0}$ menggunakan metode Next Generation Matrix (NGM), yaitu dengan membangun matriks yang membangkitkan jumlah individu baru yang terinfeksi. $R_{0}$ sebagai parameter ambang penentuan kriteria endemik penyakit pada populasi. Dari perhitungan dengan metode tersebut, diperoleh nilai $R_{0}$, yaitu

$$
R_{0}=\frac{\gamma(\beta+b+\mu+\varepsilon)}{(c+\varepsilon+\mu)(\beta+b+\mu)}
$$

3. Analisis Kestabilan Model Penyebaran Virus Influenza Tipe A H1N1

a) Kestabilan Titik Setimbang Non Endemik

Untuk menguji kestabilan titik setimbang, langkah pertama yang dilakukan adalah mensubstitusikan nilai dari titik setimbang bebas penyakit $E_{0}=\left(S^{0}, E^{0}, I^{0}, R^{0}\right)=(1,0,0,0)$ pada matriks Jacobian [9] berdasarkan Persamaan (2), yaitu

$$
J=\left[\begin{array}{cccl}
-\gamma(E+I)-\mu & -S \gamma+c & -S \gamma+b & \alpha \\
\gamma(E+I) & S \gamma-(c+\varepsilon+\mu) & \gamma S & 0 \\
0 & \varepsilon & -(\beta+b+\mu) & 0 \\
0 & 0 & \beta & -(\mu+\alpha)
\end{array}\right]
$$


Kemudian dicari dengan menggunakan $\left|\lambda I-J\left(E_{0}\right)\right|=0$

Sehingga didapatkan nilai beberapa nilai eigen, antara lain:

$$
\begin{array}{ll}
\lambda_{1}=-\mu, & \lambda_{2}=-(\mu+\alpha), \\
\lambda_{3}=-\frac{1}{2}\left(L+\sqrt{L^{2}+4 G_{1}}\right), & \lambda_{4}=-\frac{1}{2}\left(L-\sqrt{L^{2}+4 G_{1}}\right),
\end{array}
$$

dengan:

$$
L=\beta+b+c+\varepsilon+2 \mu-\gamma>0 ; G_{1}=(\beta+b+\varepsilon+\mu) \gamma-(\beta+b+\mu)(c+\varepsilon+\mu) .
$$

Titik setimbang bebas penyakit (non endemik) stabil asimtotis jika dan hanya jika persamaan karakteristik tersebut mempunyai akar-akar yang negatif. Dari persamaan karakteristik tersebut terlihat bahwa nilai eigen $\lambda_{1}, \lambda_{2}, \lambda_{3}$ selalu negatif. Jika $R_{0}<1$ maka $G_{1}<0$ sehingga $\lambda_{4}<0$. Jadi $P_{0}$ adalah stabil asimtotik. Sebaliknya jika $R_{0}>1$ sehingga $\lambda_{4}>0$, maka $P_{0}$ tak stabil.

b) Kestabilan Titik Setimbang Endemik

Langkah yang sama dilakukan dalam menentukan kestabilan titik setimbang endemik. Sehingga persamaan karakteristik dari matriks Jacobian tersebut dapat dicari dengan menggunakan $|\lambda I-J(E)|=0$ diperoleh $: \lambda^{4}+A_{1} \lambda^{3}+A_{2} \lambda^{2}+A_{3} \lambda+A_{4}=0$.

Berdasarkan kriteria Routh-Hurwitz, persamaan ini memiliki akar-akar negatif jika dan hanya jika

$$
\begin{aligned}
& \leftrightarrow A_{1}>0, A_{2}>0, A_{3}>0, A_{4}>0 \\
& \leftrightarrow A_{1} A_{2}-A_{3}>0 \\
& \leftrightarrow\left(A_{1} A_{2}-A_{3}\right) A_{3}-A_{1}^{2} A_{4}>0
\end{aligned}
$$

\section{Keterkontrolan}

Teorema 1 [4]. Jika terdapat persamaan matriks state sebagai berikut:

$\dot{x}(t)=A x(t)+B u(t)$

$y(t)=C x(t)$

Syarat perlu dan cukup suatu sistem linier dikatakan terkontrol, jika matriks

$\left(M_{c}\right)=\left(\bar{B}|\overline{A B}| \overline{A^{2} B} \mid \overline{A^{3} B}\right)$ mempunyai rank sama dengan $\mathrm{n}$.

Berdasarkan Teorema 1 [4] dapat disusun matriks keterkontrolan $\left(M_{C}\right)$ sebagai berikut:

$$
\left(M_{c}\right)=\left(\bar{B}|\overline{A B}| \overline{A^{2} B} \mid \overline{A^{3} B}\right)
$$

dan diperoleh matriks $M_{C}$ keterkontrolan seperti berikut:

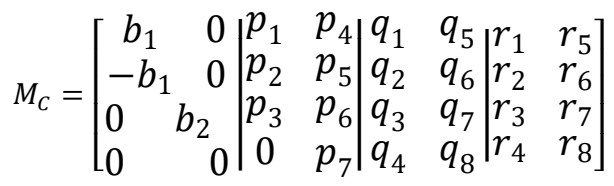


Dengan memasukkan nilai titik kesetimbangan $E_{0}$ pada matriks $M_{C}$ dan melakukan OBE diperoleh kesimpulan bahwa sistem dinamik model penyebaran penyakit bersifat terkontrol karena didapatkan rank matriks $M_{C}$ sama dengan dimensi matriks $\bar{A}$ yaitu 4, dengan demikian dapat simpulkan bahwa pada model penyebaran virus influenza tipe A bersifat terkontrol.

\section{Pembahasan}

Model dikonstruksi dengan menambahkan strategi kontrol yang diinginkan. Berikut ini diberikan beberapa asumsi yang digunakan dalam strategi kontrol pada model penyebaran virus influenza tipe A dengan resistansi penyakit pada manusia, yaitu:

1. Kontrol $u_{1}$ merupakan proporsi pemberian obat influenza.

2. Strategi kontrol $u_{2}$ merupakan upaya untuk mengurangi laju kontak penularan virus antara dari populasi rentan menjadi populasi yang terinfeksi dan terpapar melalui pengendalian lingkungan berupa penyuluhan, seminar dan juga kerja bakti.

Sehubungan dengan asumsi yang diberikan, model kontrol optimal untuk penyebaran virus influenza tipe A dapat disajikan dalam sistem persamaan diferensial sebagai berikut:

$$
\begin{aligned}
& \left.\frac{d S}{d t}=\mu-\left(1-u_{2}\right) \gamma S(t)(E(t))+I(t)\right)+c E(t)+b I(t)+\alpha R(t)-\mu S(t), \\
& \frac{d E}{d t}=\left(1-u_{2}\right) \gamma S(t)(E(t)+I(t))-(c+\varepsilon+\mu) E(t), \\
& \frac{d I}{d t}=\varepsilon E(t)-\left(\beta+b+\mu\left(1-u_{1}\right)\right) I(t) \\
& \frac{d R}{d t}=\beta I(t)-(\alpha+\mu) R(t)
\end{aligned}
$$

dengan $0 \leq u_{1} \leq 1$ dan $0 \leq u_{2} \leq 1$.

Fungsi tujuan untuk model di atas diberikan sebagai berikut:

$$
J\left(u_{1}, u_{2}\right)=\int_{0}^{t_{f}}\left(E(t)+I(t)+\frac{C_{1}}{2} u_{1}^{2}(t)+\frac{C_{2}}{2} u_{2}^{2}(t)\right) d t
$$

dimana:

$E(t)=$ jumlah individu yang terpapar yang infektif,

$I(t)=$ jumlah individu yang terinfeksi yang infektif,

$C_{1} \quad$ = bobot pada kontrol pengendalian lingkungan,

$C_{2} \quad=$ bobot pada kontrol pengobatan individu terinfeksi.

Koefisien $C_{1} \geq 0$ dan $C_{2} \geq 0$ merupakan koefisien bobot untuk meminimumkan jumlah infektif yang didasarkan pada manfaat dan biaya dari kontrol yang dilakukan.

$\int_{0}^{t_{f}}\left(\frac{C_{1}}{2} u_{1}^{2}(t)\right) d t$ : faktor biaya yang melibatkan proses pengendalian lingkungan. 
$\int_{0}^{t_{f}}\left(\frac{C_{2}}{2} u_{2}^{2}(t)\right) d t$ : faktor biaya yang melibatkan proses pengobatan individu yang terinfeksi.

Sehingga diperoleh penyelesaian kontrol optimal, yaitu:

- Bentuk fungsi Hamiltonian

$$
\begin{aligned}
H & =E(t)+I(t)+\frac{C_{1}}{2} u_{1}^{2}(t)+\frac{C_{2}}{2} u_{2}^{2}(t) \\
& \left.+\lambda_{s}\left(\mu-\left(1-u_{2}\right) \gamma S(t)(E(t))+I(t)\right)+c E(t)+b I(t)+\alpha R(t)-\mu S(t)\right) \\
& +\lambda_{E}\left(\left(1-u_{2}\right) \gamma S(t)(E(t)+I(t))-(c+\varepsilon+\mu) E(t)\right) \\
& +\lambda_{I}\left(\varepsilon E(t)-\left(\beta+b+\mu\left(1-u_{1}\right)\right) I(t)\right)+\lambda_{R}(\beta I(t)-(\alpha+\mu) R(t))
\end{aligned}
$$

- Menentukan kondisi stasioner untuk mendapatkan kontrol optimal. Persamaan H diturunkan terhadap $u_{1}$ dan $u_{2}$, sehingga diperoleh

a. $\left(\frac{\partial H}{\partial u_{1}}\right)=0$

$$
\begin{aligned}
& \Leftrightarrow 2 C_{1} u_{1}^{*}+\lambda_{I}(\mu I)=0 \\
& \Leftrightarrow u_{1}^{*}=-\frac{\lambda_{I}(\mu I)}{2 C_{1}}
\end{aligned}
$$

Karena $0 \leq u_{1} \leq 1$, sehingga

$$
u_{1}^{*}=\left\{\begin{array}{c}
0 j i k a-\frac{\lambda_{I}(\mu I)}{2 C_{1}} \leq 0 \\
-\frac{\lambda_{I}(\mu I)}{2 C_{1}} j i k a 0<-\frac{\lambda_{I}(\mu I)}{2 C_{1}}<1 \\
1 j i k a-\frac{\lambda_{I}(\mu I)}{2 C_{1}} \geq 1
\end{array}\right.
$$

Fungsi kontrol yang optimal $u_{1}^{*}$ berdasarkan tiga kemungkinan di atas dapat ditulis sebagai berikut :

$u_{1}^{*}=\min \left\{\max \left\{0,-\frac{\lambda_{I}(\mu I)}{2 C_{1}}\right\}, 1\right\}$

b. $\left(\frac{\partial H}{\partial u_{2}}\right)=0$

$$
\begin{aligned}
& \Leftrightarrow 2 C_{2} u_{2}^{*}+\lambda_{s}(\gamma S E+\gamma S)-\lambda_{E}(\gamma S E+\gamma S)=0 \\
& \Leftrightarrow 2 C_{2} u_{2}^{*}=\left(\lambda_{E}-\lambda_{S}\right)(\gamma S E+\gamma S) \\
& \Leftrightarrow u_{2}^{*}=\frac{\left(\lambda_{E}-\lambda_{S}\right)(\gamma S E+\gamma S)}{2 C_{2}}
\end{aligned}
$$

Karena $0 \leq u_{2} \leq 1$, sehingga 


$$
u_{2}^{*}=\left\{\begin{array}{c}
0 j i k a \frac{\left(\lambda_{E}-\lambda_{s}\right)(\gamma S E+\gamma S)}{2 C_{2}} \leq 0 \\
\frac{\left(\lambda_{E}-\lambda_{s}\right)(\gamma S E+\gamma S)}{2 C_{2}} \text { jika } 0<\frac{\left(\lambda_{E}-\lambda_{s}\right)(\gamma S E+\gamma S)}{2 C_{2}}<1 \\
1 \text { jika } \frac{\left(\lambda_{E}-\lambda_{s}\right)(\gamma S E+\gamma S)}{2 C_{2}} \geq 1
\end{array}\right.
$$

Fungsi kontrol yang optimal $u_{2}^{*}$ berdasarkan tiga kemungkinan di atas dapat ditulis sebagai berikut :

$u_{2}^{*}=\min \left\{\max \left\{0, \frac{\left(\lambda_{E}-\lambda_{s}\right)(\gamma S E+\gamma S)}{2 C_{2}}\right\}, 1\right\}$

- Menentukan $H$ optimal

Persamaan kontrol optimal yang diperoleh pada persamaan $u_{1}^{*}$ dan $u_{2}^{*}$ disubstitusikan ke dalam persamaan H. Sehingga diperoleh

$$
\begin{aligned}
H^{*} & =E(t)+I(t)+\frac{C_{1}}{2}\left(u_{1}^{*}\right)^{2}(t)+\frac{C_{2}}{2}\left(u_{2}^{*}\right)^{2}(t) \\
& \left.+\lambda_{s}\left(\mu-\left(1-u_{2}^{*}\right) \gamma S(t)(E(t))+I(t)\right)+c E(t)+b I(t)+\alpha R(t)-\mu S(t)\right) \\
& +\lambda_{E}\left(\left(1-u_{2}^{*}\right) \gamma S(t)(E(t)+I(t))-(c+\varepsilon+\mu) E(t)\right) \\
& +\lambda_{I}\left(\varepsilon E(t)-\left(\beta+b+\mu\left(1-u_{1}^{*}\right)\right) I(t)\right)+\lambda_{R}(\beta I(t)-(\alpha+\mu) R(t))
\end{aligned}
$$

- Menyelesaikan persamaan state dan costate untuk memperoleh sistem yang optimal

a. Persamaan state

$$
\begin{aligned}
& \left.\dot{S}^{*}=\frac{\partial H^{*}}{\partial \lambda_{s}}=\mu-\left(1-u_{2}^{*}\right) \gamma S(t)(E(t))+I(t)\right)+c E(t)+b I(t)+\alpha R(t)-\mu S(t) \\
& \dot{E}^{*}=\frac{\partial H^{*}}{\partial \lambda_{E}}=\left(1-u_{2}^{*}\right) \gamma S(t)(E(t)+I(t))-(c+\varepsilon+\mu) E(t) \\
& \dot{I}^{*}=\frac{\partial H^{*}}{\partial \lambda_{I}}=\varepsilon E(t)-\left(\beta+b+\mu\left(1-u_{1}^{*}\right)\right) I(t) \\
& \dot{R}^{*}=\frac{\partial H^{*}}{\partial \lambda_{R}}=\beta I(t)-(\alpha+\mu) R(t)
\end{aligned}
$$

b. Persamaan costate

$$
\begin{aligned}
& \dot{\lambda}_{s}=-\frac{\partial H}{\partial S}=\left[\lambda_{S}-\lambda_{E}\right]\left[\gamma\left(1-u_{2}^{*}\right)(E+I)\right]+\lambda_{S} \mu \\
& \dot{\lambda}_{E}=-\frac{\partial H}{\partial E}=-1+\gamma S\left[1-u_{2}^{*}\right]\left[\lambda_{S}-\lambda_{E}\right]+\lambda_{E}(c-\varepsilon+\mu)-c \lambda_{S}-\varepsilon \lambda_{I} \\
& \dot{\lambda}_{I}=-\frac{\partial H}{\partial I}=-1-b \lambda_{S}+\gamma S\left[1-u_{2}^{*}\right]\left[\lambda_{S}-\lambda_{E}\right]+\lambda_{I}\left[\mu\left(1-u_{1}^{*}\right)+\beta+b\right]-\beta \lambda_{R} \\
& \dot{\lambda}_{R}=-\frac{\partial H}{\partial R}=[\alpha+\mu] \lambda_{R}-\alpha
\end{aligned}
$$




\section{Hasil Simulasi}

Padasimulasi ini dibuat 2 kondisi. Kondisi pertama untuk melihat perubahan banyaknya individu di setiap populasi pada saat $R_{0}<0$ dan kondisi kedua ketika $R_{0}>0$. Metode yang digunakan pada simulasi ini adalah metode Runge-Kutta Orde 4 dan metode Sweep ForwardBackward dengan menggunakan software Matlab. Adapun nilai awal dari setiap subpopulasi yang diberikan yaitu sebagai berikut:

Tabel 1. Nilai Awal Sub-Populasi

\begin{tabular}{ccc}
\hline Subpopulasi & Nilai Awal & Sumber \\
\hline$S(t)$ & 0.4 & {$[5]$} \\
$E(t)$ & 0.15 & {$[5]$} \\
$I(t)$ & 0.25 & {$[5]$} \\
$R(t)$ & 0.2 & {$[5]$} \\
\hline
\end{tabular}

Dari gambar yang diberikan, diasumsikan bahwa faktor penyeimbang $C_{2}$ yang diasumsikan dengan kontrol $u_{2}$ lebih besar atau sama dengan faktor penyeimbang $C_{1}$ yang diasumsikan dengan kontrol $u_{1}$. Anggapan ini berdasarkan fakta bahwa biaya yang diasumsikan dengan kontrol $u_{1}$ akan mengikutsertakan biaya pengendalian lingkungan (penyuluhan, seminar, kerja bakti) dan biaya yang diasumsikan dengan $u_{2}$ akan mengikutsertakan biaya pengobatan. Pada gambar, faktor bobot, $C_{1}=15$ dan $C_{2}=20$, dipilih untuk menggambarkan strategi penanganan optimal. Parameter lain diberikan pada tabel dibawah ini:

Tabel 2. Nilai Parameter

\begin{tabular}{ccc}
\hline Parameter & Nilai & Sumber \\
\hline$\mu$ & 0.015 & {$[3]$} \\
$b$ & 0.025 & {$[3]$} \\
$c$ & 0.35 & {$[3]$} \\
$\varepsilon$ & 0.15 & {$[3]$} \\
$\alpha$ & 0.35 & {$[3]$} \\
$\beta$ & 0.5 & {$[3]$} \\
$\gamma$ & 0.1 & {$[3]$} \\
\hline
\end{tabular}

Dari nilai-nilai parameter yang diberikan pada Tabel 2, didapatkan nilai reproduksi dasar sebagai berikut:

$$
R_{0}=\frac{\gamma(\beta+b+\mu+\varepsilon)}{(c+\varepsilon+\mu)(\beta+b+\mu)}=\frac{(0.1)(0.69)}{(0.515)(0.54)}=0.2481
$$

Berdasarkan nilai $R_{0}$, performansi simulasi numerik dapat diberikan pada Gambar 2 sebagai berikut : 


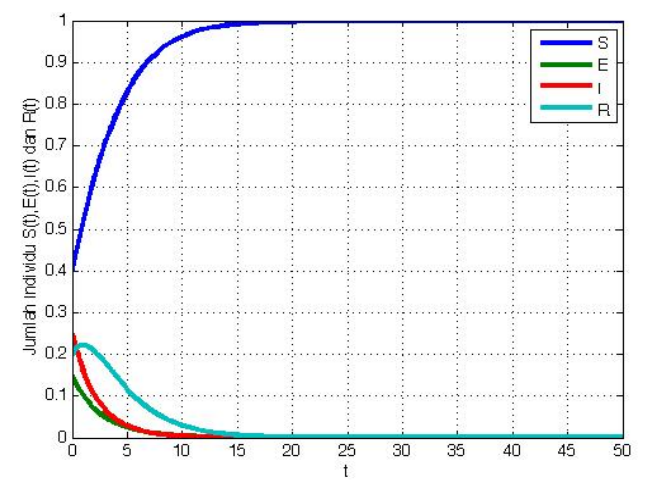

Gambar 2. Grafik Perubahan banyaknya individu untuk $R_{0}<1$

Berdasarkan Gambar 2 terlihat bahwa banyaknya individu susceptible terus bertambah. Hal tersebut disebabkan oleh tingginya tingkat kelahiran dan menurunnya daya tahan tubuh pada individu recovered. Disisi lain, adanya kematian alami yang menyebabkan individu exposed, infected dan recovered semakin berkurang. Sehingga pada akhirnya akan menuju titik kesetimbangan bebas penyakit. Untuk simulasi numerik saat kondisi 2 yaitu ketika $R_{0}>0$, yang artinya individu yang terinfeksi memproduksi lebih dari satu individu terinfeksi baru, dengan kata lain dapat diprediksi bahwa infeksi akan menyebar pada populasi. Nilai parameter yang digunakan pada Tabel 2 dengan memperbesar nilai parameter $\gamma$ menjadi 0.5. Kemudian simulasi yang dilakukan pada kondisi $R_{0}>0$ adalah menunjukkan pengaruh kontrol pengobatan dan kontrol pengendalian lingkungan yang diberikan. Sehingga dapat dibuat simulasi perubahan banyaknya individu pada setiap subpopulasi sebelum diberikan kontrol dan setelah diberikan kontrol.

Selanjutnya, berdasarkan pada Tabel 2, dapat dihasilkan simulasi yang tampak pada gambar berikut:

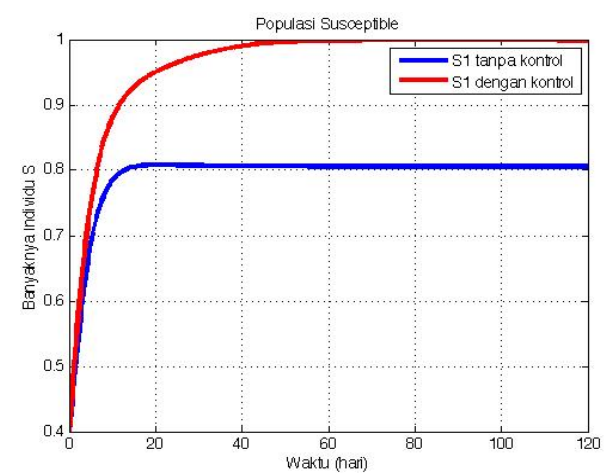

Gambar 3. Grafik perbandingan perubahan banyaknya individu Susceptible tanpa dan dengan kontrol

Berdasarkan Gambar 3 banyaknya individu Susceptible tanpa kontrol mengalami peningkatan sampai akhirnya stabil mulai hari ke-40 dengan jumlah 810 individu. Kemudian 
setelah diberikan kontrol pengobatan pada individu infected, banyaknya individu susceptible mengalami peningkatan dan stabil mulai hari ke-75 dengan jumlah 990 individu.

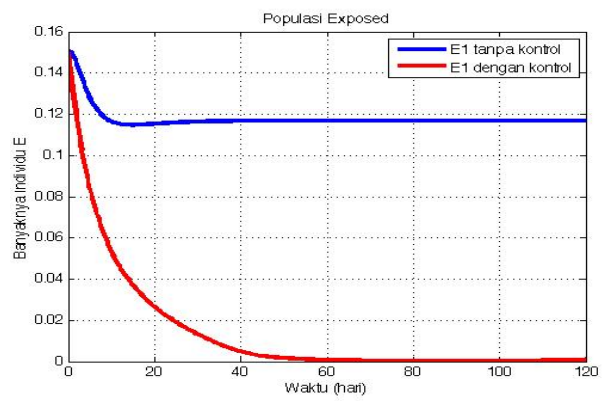

Gambar 4. Grafik perbandingan perubahan banyaknya individu Exposed tanpa dan dengan kontrol

Berdasarkan Gambar 4 banyaknya individu Exposed tanpa kontrol mengalami penurunan dan stabil pada hari ke-40 dengan jumlah 120 individu. Menurunnya populasi exposed dikarenakan besarnya pengaruh parameter $\gamma$. Jika nilai $\gamma$ semakin besar, maka jumlah individu tanpa kontrol akan semakin berkurang. Sedangkan banyaknya individu setelah diberikan kontrol mengalami penurunan dan stabil pada hari ke-60.

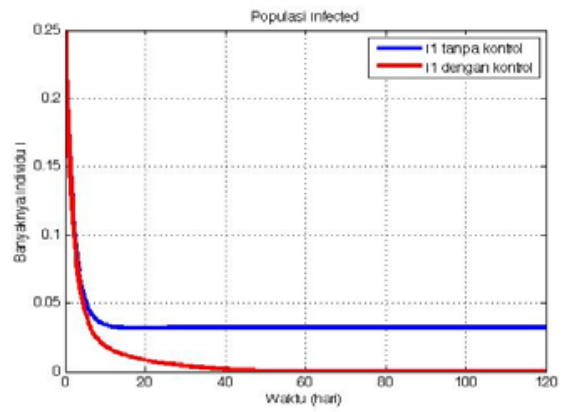

Gambar 5. Grafik perbandingan perubahan banyaknya individu Infected tanpa dan dengan kontrol

Berdasarkan Gambar 5 banyaknya individu Infected tanpa kontrol mengalami penurunan dan stabil pada hari ke-36. Sedangkan setelah diberikan kontrol mengalami penurunan lebih tajam dan stabil pada hari ke-56. Hal ini menunjukkan bahwa tingkat efektifitas pada pemberian kontrol populasi Infected memberikan pengaruh yang nyata. 


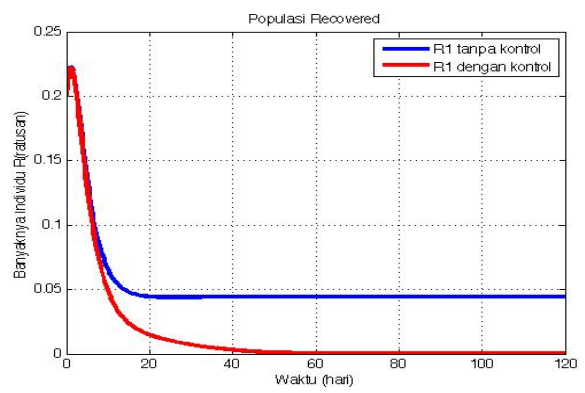

Gambar 6. Grafik perbandingan perubahan banyaknya individu Recoered tanpa dan dengan kontrol

Berdasarkan Gambar 6 banyaknya individu Recovered tanpa kontrol mengalami penurunan sampai akhirnya stabil mulai hari ke-40. Kemudian setelah diberikan kontrol, banyaknya individu Recovered mengalami penurunan lalu stabil mulai hari ke-60.

\section{Simpulan}

- Kontrol optimal yang diperoleh dari model matematika penyebaran virus influenza tipe A menggunakan metode Pontryagin Minimum Principle yaitu

$u_{1}^{*}=-\frac{\lambda_{I}(\mu I)}{C_{1}}$

$u_{2}^{*}=\frac{\left(\lambda_{E}-\lambda_{S}\right)(\gamma S E+\gamma S)}{C_{2}}$,

dengan:

$u_{1}=$ kontrol berupapengobatan individu yang terinfeksi,

$u_{2}=$ kontrol berupa pengendalian lingkungan (penyuluhan, seminar dan kerja bakti).

- Berdasarkan hasil simulasi numerik yang telah dilakukan, menunjukkan bahwa pemberian kontrol optimal dapat meminimumkan jumlah individu yang meninggal karena terinfeksi virus influenza tipe A dan meminimalisir laju kontak penularan virus yang ada sehingga didapatkan penurunan jumlah populasi terpapar dan terinfeksi.

\section{Daftar Pustaka}

[1] N. M. Ferguson, S. Mallett, H. Jackson, N. Roberts, and P. Ward, “A population-dynamic model for evaluating the potential spread of drug-resistant influenza virus infections during community-based use of antivirals," J. Antimicrob. Chemother., vol. 51, no. 4, pp. 977-990, 2003, doi: 10.1093/jac/dkg136.

[2] X. Zhou and Z. Guo, "Analysis of an influenza A (H1N1) epidemic model with vaccination,” Arab. J. Math., vol. 1, no. 2, pp. 267-282, 2012, doi: 10.1007/s40065-0120013-6. 
[3] N. H. Khanh, "Stability analysis of an influenza virus model with disease resistance," J. Egypt. Math. Soc., vol. 24, no. 2, pp. 193-199, 2016, doi: 10.1016/j.joems.2015.02.003.

[4] L. Perko, Equations and Dynamical Systems. 2001.

[5] L. Rochmatika, S. Winarko, and L. Hanafi, "Penyelesaian Numerik dan Analisa Kestabilan pada Model Epidemik SEIR dengan Memperhatikan Adanya Penularan pada Periode Laten," pp. 1-6, 2013. 